\title{
Peran Penyuluh Agama Islam Fungsional dalam Pembinaan Perkawinan Di Kabupaten Sleman (Tinjauan Konseling Islam)
}

\author{
Surahmat \\ Universitas Muhammadiyah Yogyakarta \\ surahmatannashih@gmail.com
}

\begin{abstract}
Abstrak: KUA (Kantor Urusan Agama) merupakan pihak pemerintah yang paling dibutuhkan dalam urusan perkawinan. Di dalam strukturnya ada Penghulu yang bertugas dalam pelayanan pencatatan perkawinan, Staf Pembinaan Perkawinan dan Keluarga Sakinah (Binwin KS) yang bertugas dalam pembinaan perkawinan dan keluarga sakinah, dan Penyuluh Agama Islam Fungsional (PAIF) yang bertugas dalam bimbingan penyuluhan agama Islam. Dalam kasus di Kabupaten Sleman, DIY; peran ideal PAIF dalam pembinaan perkawinan (binwin) sudah bersifat Islami dan legal. Adapun kegiatannya terkelompok dalam 8 peran (P), yakni menjadi narasumber: penasihatan calon pengantin (catin) individual (P1), penasihatan catin berpasangan/ sepasang (P2), penasihatan catin klasikal/ kursus catin (P3), panitia kursus catin (P4), khutbah nikah (P5), penasihatan pascanikah individual (P6), penasihatan pascanikah berpasangan (P7), dan menjadi Konsultan Perkawinan BP4 (P8). Dari 8 peran ideal tersebut yang dapat diperankan oleh para PAIF sebagai peran aktual di KUA se-Kabupaten Sleman adalah: P1, P2, P3, P6, P7, dan P8 dengan signifikasi peran yang berbeda-beda; ada yang berperan secara signifikan (S), cukup signifikan (CS), kurang signifikan (KS), dan ada pula yang tidak signifikan (TS). Dari tinjauan Konseling Islam, baik peran ideal maupun peran aktual PAIF itu menunjukkan relevansi dengan standar Konseling Islam. Relevansi ini dapat dianalisis keterkaitannya dengan strategi optimalisasi peran PAIF dalam binwin.
\end{abstract}

Kata kunci: Peran, Penyuluh, Bimbingan Perkawinan, Konseling Islam

Abstract: KUA (Kantor Urusan Agama / Office of Religious Affairs) is a part of the government that is needed the most in marriage affairs. In its structure, there are Marriage Registrar who works in marriage registration service, Staff of Pembinaan Perkawinan dan Keluarga Sakinah (Binwin KS) who works in marriage consultation and family with tranquility and Functional Islam Religion Counsellor (Penyuluh Agama Islam Fungsional/ PAIF) who works Islam religion guidance and counselling. In the case in Sleman Regency of DIY (Daerah Istimewa Yogyakarta/ Yogyakarta Special Region; the ideal role of PAIF in marriage consultation (binwin) has had Islamic characteristics and legal. Meanwhile, the activities are categorized into 8 roles ( $P$ ), as follows becoming: consultation resource person of future brides and bridegrooms individually (P1), consultation resource person of future brides and bridegrooms in couple (P2), consultation resource person of future brides and bridegrooms in a class/ in course (P3), course committee of future brides and bridegrooms individually (P4), in marriage khutbah (P5), consultation resource person of post marriage individually (P6), consultation resource person of post marriage in couple (P7), and becoming BP4 Marriage Consultant. Among the ideal 8 roles, the actual roles of PAIFs in KUA in Sleman Regency are P1, P2, P3, P6, P7, and P8 with different significance of the roles; there are ones with roles that are significant (S), significant enough (CS), less significant (KS), and not significant (TS). From Islamic Counselling review, both ideal role and actual role of PAIF show a relevance with Islamic Counselling standard. The correlation of the relevance and the role optimization strategy of PAIF in binwin can be analyzed.

Keywords: Role, Counsellor, Marriage Consultation, Islamic Counselling

Al-Manar : Jurnal Komunikasi dan Pendidikan Islam - Volume 10, Nomor 1, Juni 2021 


\section{PENDAHULUAN}

Sebagai makhluk sosial manusia selalu membutuhkan manusia lain, baik dalam kondisi bahagia maupun susah. Dikatakan demikian karena ia membutuhkan respon positif dari sesamanya pada saat mengekspresikan kebahagiaan maupun ketika mengeluhkan kesusahan. Respon positif tersebut sangat dibutuhkan oleh manusia. Jika kebutuhan itu tidak terpenuhi maka ia dirundung kegelisahan. Dengan demikian ia membutuhkan respon positif dalam berbagai aspek kehidupan.

Perkawinan merupakan salah satu aspek kehidupan. Sebagai individu manusia membutuhkan sesamanya dalam menjalani seluruh prosesnya. Proses tersebut meliputi: mempersiapkan perkawinan, melangsungkan perkawinan, membina rumah tangga, dan mencari solusi atas problematika rumah tangga. Dalam hal ini ia membutuhkan bantuan dan dukungan dari banyak pihak, yaitu: keluarga, masyarakat, dan pemerintah.

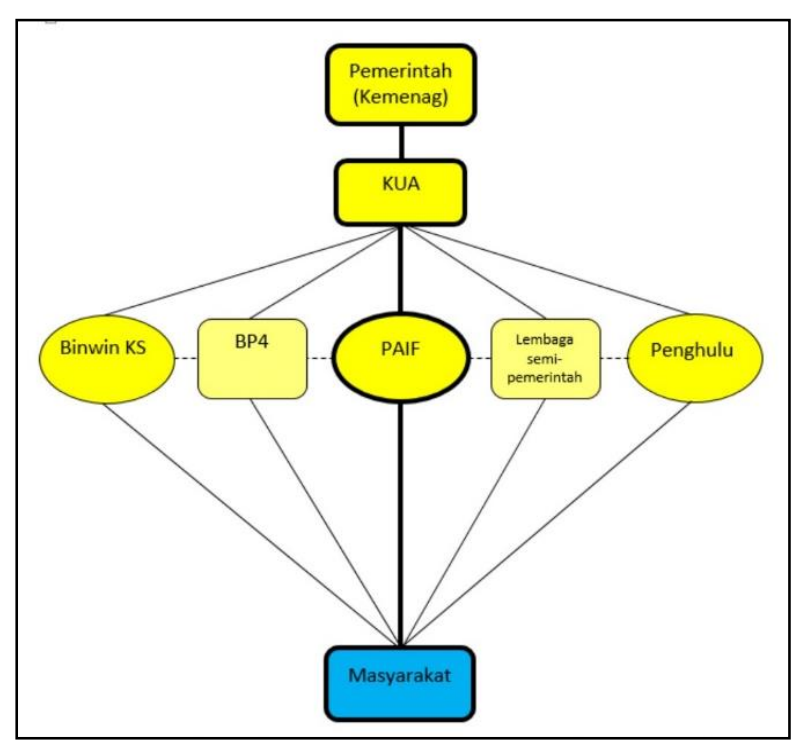

Gambar 1. Posisi Strategis PAIF Dalam Melavani Masvarakat
Kantor Urusan Agama (KUA) merupakan pihak pemerintah yang paling dibutuhkan dalam urusan perkawinan. Di dalam strukturnya ada Penghulu yang berperan dalam pelayanan pencatatan perkawinan dan Penyuluh Agama Islam Fungsional (PAIF) yang berperan dalam bimbingan perkawinan (binwin).

Sinergitas di KUA berpotensi menempatkan PAIF pada posisi strategis. Posisi demikian menjadi faktor pendukung bagi terlaksananya tugas PAIF dalam melayani masyarakat. Realisasi pelaksanaan tugas tersebut bergantung kepada PAIF; sejauh mana ia merespon posisinya dengan berperan dalam kegiatan-kegiatan real yang legal. Dikatakan legal karena sesuai dengan tugas pokok dan fungsi (tupoksi) PAIF, serta selaras dengan visi dan misi Kantor Kementerian Agama (Kemenag) Kabupaten/ Kota yang membina KUA tempatnya berkantor.

Penelitian ini fokus pada tinjauan teori atas peran PAIF dalam binwin dari perspektif Konseling Islam dengan mengambil kasus di Kabupaten Sleman, DIY. Targetnya mengungkap kepekaan PAIF dalam pelayanan binwin di KUA. Adapun rumusan masalahnya adalah: 1) Bagaimana peran ideal dan aktual PAIF dalam binwin 
di Kabupaten Sleman? 2) Apakah peran PAIF dalam binwin sudah relevan dengan standar Konseling Islam? 3) Strategi apa saja yang harus ditempuh guna mengoptimalisasikan peran PAIF dalam binwin agar relevan dengan standar Konseling Islam?

\section{METODE PENELITIAN}

Jenis penelitian ini adalah penelitian lapangan (field research) dengan pendekatan kualitatif. Hal ini didasari oleh asumsi bahwa realitas bersifat subjektif dan ganda, artinya setiap PAIF, pejabat/ pegawai Kemenag dan pengurus BP4 merupakan individu-individu yang unik dengan pola pikir dan perilaku yang beragam terhadap suatu masalah.

Selain itu, mengingat penelitian lapangan berorientasi pada pemahaman mendalam terhadap setiap individu maupun kelompok yang diteliti maka penelitian ini membutuhkan kedekatan antara peneliti dan yang diteliti ${ }^{1}$. Adapun penelitian ini dimaksudkan untuk memahami secara mendalam tentang peran PAIF, yakni mendeskripsi dan menganalisis berbagai aktivitasnya dalam binwin. Dengan demikian peneliti harus melakukan interaksi intensif dengan lokasi dan subjek penelitian agar diperoleh data-data yang natural. Secara keseluruhan penelitian ini mendiskripsikan tentang ada tidaknya relevansi antara peran PAIF tersebut dengan standar Konseling Islam pada studi kasus di Kabupaten Sleman.

Penelitian ini dilakukan pada bulan Januari sampai Nopember tahun 2017 dengan lokasi Kabupaten Sleman. Wilayahnya terdiri dari 17 kecamatan yang masingmasing memilik 1 unit KUA, dan masing-masing KUA meyediakan meja khusus untuk PAIF dengan jumlah PAIF yang bervariasi. Selain data tersebut juga ditemukan realita bahwa keberadaan BP4 di 17 kecamatan tersebut dikategorkan tidak signifikan. Dikatakan tidak signifikan karena organisasi tersebut sudah lama tidak berjalan, baik secara struktur maupun fungsi. Faktor penyebab utamanya adalah ketiadaan dana, artinya organisasi semiresmi ini sudah lama tidak mendapatkan subsidi dana dari pemerintah².

Sebagaimana kelaziman metode penelitian kualitatif yang bertumpu pada wawancara mendalam kepada informan baik informan pangkal maupun informan kunci $^{3}$ penelitian inipun bertumpu pada hal tersebut. Informan pangkal (yang kriterianya adalah dapat memberikan keterangan atau data yang berkaitan dengan

\footnotetext{
${ }^{1}$ Khilmiyah, Akif. 2016. Metode Penelitian Kualitatif. Yogyakarta: Samudra Biru. 160-161

2 Disarikan dari sumber: Forum diskusi dan pembinaan Pokjaluh (Kelompok Kerja Penyuluh Agama Islam Fungsional) Kabupaten Sleman, Selasa 9 Maret 2017 di RM Shiva, Ngaglik Sleman.

${ }^{3}$ Ismail, Nawari. 2015. Metodologi Penelitian Untuk Studi Islam Panduan Praktis dan Diskusi Isu. Yogyakarta: Samudra Biru. 88
}

Al-Manar : Jurnal Komunikasi dan Pendidikan Islam - Volume 10, Nomor 1, Juni 2021 
setting penelitian) yang diwawancarai adalah: 1) Pejabat/ pegawai di Kemenag Kabupaten Sleman dalam konteks keterangan atau data yang berkaitan dengan setting penelitian secara umum; 2) Pengurus Kelompok Kerja Penyuluh (Pokjaluh) Kabupaten Sleman dalam konteks keterangan atau data yang berkaitan dengan setting penelitian secara umum; dan 3) Pejabat/ pegawai di KUA dalam konteks keterangan atau data yang berkaitan dengan setting penelitian secara khusus/ detail, terutama tentang pelayanan perkawinan. Sedangkan informan kunci (yang kriteranya adalah dapat memberikan keterangan atau data yang berkaitan dengan subjek penelitian dan segala perannya pada setting penelitian) yang diwawancarai adalah PAIF seKabupaten Sleman.

Subjek penelitian dalam penelitian ini adalah PAIF di Kabupaten Sleman. Penentuan subjek tersebut menggunakan cara purposive sampling atau criterian based selection dengan fokus mendapatkan subjek PAIF yang paling berpotensi dalam memberikan keterangan atau data tentang: 1) Signifikasi peran PAIF dalam keguatan binwin, dan 2) Ragam dan proses kegiatan PAIF dalam binwin.

Adapun kriteria subjek penelitiannya adalah: 1) Berjabatan PAIF, 2) Mendapat tugas resmi kedinasan sebagai PAIF pada salah satu kecamatan di Kabupaten Sleman, 3) Mengambil peran dalam kegiatan binwin di KUA sekurang-kurangnya dalam periode pembinaan bulan Januari sampai Nopember 2017, dan 4) Mampu menjelaskan proses kegiatan binwin di KUA yang dijalani sendiri.

Penentuan subjek penelitian pada penelitian ini tidak didasarkan pada banyaknya informan tetapi didasarkan pada tingkat kejenuhan jawaban-jawaban dari informan. Secara teknis, pengambilan hasil (keterangan atau data tersebut) tersentral pada para PAIF yang mengambil peran signifikan dalam binwin (sebagai subjek utama), sedangkan para PAIF selainnya adalah informan-informan pendukung sejauh data yang dibutuhkan. Prinsip penentuan informan ini difokuskan pada tercapainya perolehan keterangan atau data yang natural (benar, akurat, lengkap, dan mendalam).

Teknik pengumpulan data penelitian menggunakan metode: 1) wawancara mendalam, 2) pengamatan terlibat, 3) perbincangan, 4) focus group discussion (FGD), dan 5) dokumentasi. Analisis data dilakukan secara kualitatif, yakni sejak penyajian, penyimpulan, sampai verikasi hasil penelitian. Adapun kredibilitas penelitian diukur melalui pengujian bertahap.

\section{PEMBAHASAN}

Dalam penelitian ini ada 3 konsep yang harus diungkapkan secara operasional, yaitu: peran PAIF, binwin, dan Konseling Islam. Yang pertama, peran PAIF. Kata "peran" berarti: "pemain sandiwara (film)", dan kata "peranan" diartikan sebagai: 1) 
"bagian yang dimainkan seorang pemain (dalam film, sandiwara, dan sebagainya)" dan 2) "fungsi seseorang atau sesuatu dalam kehidupan"4. Esensi peranan adalah partisipasi dan fungsi, atau menunjuk pada posisi subjektif dari peran (pemain). Dalam konteks individu, peran mengandung arti: "individu sebagai subjek (pelaku) yang memainkan partisipasi dan fungsinya". Maka definisi umum peran ialah posisi subjektif terkait partisipasi dan fungsi.

"Peran" merupakan konsep ilmu Sosiologi5. Mendefinisikannya harus merujuk disiplin ilmu tersebut, yakni memadukan definisi umum dengan definisi keilmuan. Dengan demikian definisi ilmiah yang dihasilkan dapat diaplikasikan/ dioperasionalisasikan pada setting penelitian yang sedang dilakukan.

"Peranan" merupakan konsep tentang apa yang dapat dilakukan oleh individu atau sekelompok individu dalam masyarakat sebagai organisasi ${ }^{6}$. Esensi sebuah peranan terletak pada tanggung jawab sosiologis dari individu atau kelompok. Jika digabungkan dengan definisi umumnya maka esensi peran adalah posisi subjektif yang bertumpu pada aspek: partisipasi, fungsi, dan tanggung jawab; baik dalam posisi individu maupun kelompok.

Dalam konteks PAIF, konsep peran bertumpu pada konsep "penyuluh". Konsep ini terkait dengan ilmu Konseling. Adapun "peran PAIF" masuk dalam konsep ilmu Sosiologi Konseling. Maka "peran PAIF dalam binwin" didefinisikan sebagai posisi subjektif PAIF pada upaya mengaktualisasikan partisipasi, fungsi, dan tanggung jawabnya pada pelayanan binwin. Selanjutnya peran tersebut ditinjau dari perspektif ilmu Konseling Islam.

Sebagai pejabat fungsional, PAIF harus memainkan perannya secara legal (sesuai dengan tugas pokok dan fungsi). Tugas pokoknya adalah melakukan dan mengembangkan kegiatan bimbingan atau penyuluhan agama dan pembangunan melalui bahasa agama7, yakni Agama Islam. Berdasarkan tugas pokoknya fungsi PAIF telah diatur menjadi 3 fungsi pokok, yaitu fungsi: 1) informatif dan edukatif, 2) konsultatif, dan 3) advokatif ${ }^{8}$. Ketiganya menjadi dasar pelaksanaan tugas PAIF dalam melayani masyarakat, termasuk pada pelayanan binwin.

Kedua, binwin (pembinaan pekawinan). Kata "bina" atau "membina" berarti:1) "membangun; yaitu mendirikan (negara dan sebagainya)", dan 2) "mengusahakan

${ }^{4}$ Kamus, Tim Penyusun. 2008. Kamus Bahasa Indonesia. Jakarta: Pusat Bahasa Departemen Pendidikan Nasional. 1155

${ }^{5}$ Ismail, Nawari. 2015. Metodologi ...... 25

${ }^{6}$ Soerjono, Soekanto. 1990. Sosiologi Suatu Pengantar. Jakarta: PT Raja Grafindo Persada. 269

7 Masyarakat, Bidang Pendidikan Agama Islam Pada. 2010. Buku Pedoman Penyuluh Seri I. Yogyakarta: Kanwil Kementerian Agama DIY. 281

${ }^{8}$ Masyarakat, Bidang Pendidikan Agama Islam Pada. 2010. Buku .... 281-282 
supaya lebih baik (maju, sempurna, dan sebagainya)"9. Selanjutnya kata "kawin" merupakan: 1) kata benda yang berarti: "perjodohan laki-laki dengan perempuan menjadi suami-istri; atau disebut nikah", dan 2) kata kerja dengan arti: "beristri atau bersuami; atau disebut nikah", juga diartikan: "bersetubuh". Sedangkan "perkawinan" adalah kata benda yang artinya: "pernikahan; yaitu hal (urusan dan sebagainya tentang) kawin"10. Esensi pembinaan adalah proses mendirikan dan meningkatkan kualitas suatu bangunan (sistem); dan esensi perkawinan adalah melakukan pernikahan. Maka definisi umum pembinaan perkawinan ialah proses mendirikan dan meningkatkan kualitas bangunan pernikahan.

Dalam konteks tupoksi PAIF binwin harus merujuk ketentuan agama dan perundangan. Undang-Undang RI Nomor 1 Tahun 1974 tentang Perkawinan pasal 1 mendefinisikan bahwa perkawinan ialah ikatan lahir batin antara seorang pria dengan seorang wanita sebagai suami istri dengan tujuan membentuk keluarga (rumah tangga) yang bahagia dan kekal berdasarkan Ketuhanan Yang Maha Esa ${ }^{11}$. Definisi ini

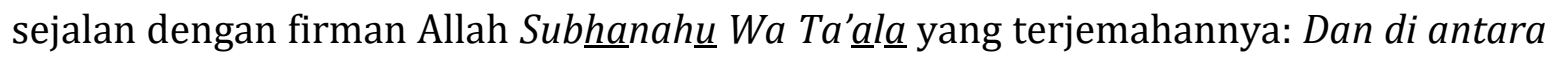
tanda-tanda (kebesaran)-Nya ialah Dia menciptakan pasangan-pasangan untukmu dari jenismu sendiri, agar kamu cenderung dan merasa tenteram kepadanya, dan Dia menjadikan di antaramu rasa kasih dan sayang.....12. (QS: 30.Ar-Rum : 21) yang tersirat tujuan (perkawinan) untuk mewujudkan keluarga yang tenteram (sakinah). Dipertegas oleh tafsiran Kemenag RI bahwa tujuan perjodohan (perkawinan) adalah agar manusia dapat hidup tenteram dan saling mencintai dalam rumah tangga yang tenang dan damai ${ }^{13}$. Maka bimbingan perkawinan didefinisikan sebagai proses mengusahakan berdirinya bangunan rumah tangga (keluarga) dan meningkatkannya menjadi lebih baik untuk mewujudkan keluarga yang sakinah.

Dalam konteks PAIF, lingkup kegiatan binwin meliputi: 1) binwin di KUA, dan 2) binwin di luar KUA. Adapun binwin pada konteks penelitian ini adalah binwin di KUA. Sampai di sini didefinisikan bahwa "peran PAIF dalam binwin" adalah posisi subjektif PAIF pada upaya mengaktualisasikan partisipasi, fungsi, dan tanggung jawabnya pada pelayanan binwin di KUA, baik yang dilakukan oleh PAIF secara

9 Kamus, Tim Penyusun. 2008. Kamus .... 201

10 Kamus, Tim Penyusun. 2008. Kamus ... 697-698

11 Undang-Undang Republik Indonesia Nomor 1 Tahun 1974 Tentang Perkawinan dalam: Indonesia, Direktorat Jenderal Bimbingan Masyarakat Islam Kementerian Agama Republik. 2015. Himpunan Peraturan Perundang-Undangan Perkawinan. Jakarta: Direktorat Jenderal Bimbingan Masyarakat Islam Kementerian Agama Republik Indonesia. 22

12 RI, Kementerian Agama. 2012. Al-Qur'an Dan Terjemahnya. Jakarta: Kementerian Agama RI Direktorat Jendral Bimbingan Masyarakat Islam Dan Pembinaan Syariah. h. 572

13 RI, Kementerian Agama. 2012. Al-Qur'an Dan Tafsirnya Jilid 7. Jakarta: Kementerian Agama RI Direktorat Jendral Bimbingan Masyarakat Islam Dan Pembinaan Syariah. 478 
individu maupun bekerja sama dalam suatu kelompok. Upaya tersebut merupakan bagian dari proses mengusahakan berdirinya bangunan rumah tangga (keluarga) dalam koridor perkawinan yang dicatat oleh KUA, dan meningkatkannya menjadi lebih baik guna mewujudkan keluarga yang sakinah menurut ketentuan keislaman dan perundangan.

Adapun yang ketiga, Konseling Islam. Kata "konseling" artinya "pemberian bimbingan oleh orang yang ahli kepada seseorang dengan menggunakan metode psikologis"14. Secara keilmuan "konseling" dirumuskan dalam definisi tertentu. H. B. Inglish and English mendefinisikannya sebagai "a relationship in witch one person endeavors to help another to understand and to solve his adjustment problems"15. Sedangkan Hahn membuat definisi:

.... a proces witch takes place in a one-to-one relationship between an individual by problem witch he can not cope alone, and a profesional worker whose training an experience have qualified him to help others reach solution to various types of personal difficulties ${ }^{16}$.

Adapun Kusno Effendi mendefinisikannya sebagai hubungan atau interaksi antara dua orang karena adanya kebutuhan untuk membantu dan kebutuhan untuk dibantu ${ }^{17}$.

Kata "konseling Islam" bermakna "konseling dengan ciri Islam". Definisi operasionalnya diupayakan secara morfologis dengan mengubah kata benda "Islam" menjadi kata sifat "Islami" yang artinya "bersifat keislaman"18. Maka konsep konseling Islam dapat dioperasionalisasikan sebagai konseling Islami (konseling yang bersifat keislaman). Sebagai sebuah proses interaksi pemberian bantuan dan bimbingan sebenarnya konseling sudah menunjukkan sifat Islami, yakni pada ajaran ta'a wun

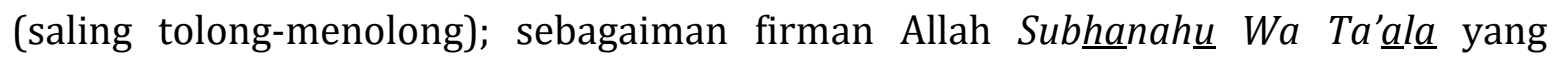
terjemahannya: ..... Dan tolong-menolonglah kamu dalam (mengerjakan) kebajikan dan takwa, dan jangan tolong-menolong dalam berbuat dosa dan permusuhan..... ${ }^{19}$ (QS: 5.Al-Maidah : 2)

Sampai di sini definisi Effendy dapat dipandang lebih mendekati sifat Islami daripada definisi Inglish and English dan Hahn. Sebab definisi tersebut lebih tegas menunjukkan keseimbangan kebutuhan (saling membutuhkan) antara konselor dan

14 Kamus, Tim Penyusun. 2008. Kamus .... 802

15 Effendi, Kusno. 2016. Proses dan Keterampilan Konseling. Yogyakarta: Pustaka Pelajar. 15

16 Effendi, Kusno. 2016. Proses .... 15-16

17 Effendi, Kusno. 2016. Proses .... 16

${ }^{18}$ Kamus, Tim Penyusun. 2008. Kamus .... 601

${ }^{19}$ RI, Kementerian Agama. 2012. Al-Qur'an .... 142 
klien, sedangkan kedua definisi lainnya tidak dengan tegas menunjukkan keseimbangan tersebut. Anwar Sutoyo merumuskan bahwa:

.... konseling Islami adalah aktivitas yang bersifat "membantu", dikatakan membantu karena pada hakikatnya individu sendirilah yang perlu hidup sesuai tuntunan Allah (jalan yang lurus) agar mereka selamat. Karena posisi konselor bersifat membantu, maka konsekwensinya individu sendiri yang harus aktif belajar memahami dan sekaligus melaksanakan tuntunan Islam (Al-Qur'an dan sunnah rasul-Nya). Pada akhirnya diharapkan agar individu selamat dan memperoleh kebahagiaan yang sejati di dunia dan akhirat, bukan sebaliknya kesengsaraan dan kemelaratan di dunia dan akhirat ${ }^{20}$.

Sutoyo menitik beratkan proses dan hasil dari konseling adalah pada kesesuaiannya dengan tuntunan Islam. Maksudnya adalah adanya nilai-nilai keislaman dari proses konseling dan solusi yang diberikan. Nilai-nilai tersebut menjadi karakter khas dari konseling Islam. Pada konteks penelitian ini, nilai-nilai itu disebut nilai-nilai keislaman dalam Konseling Islam.

Merujuk pada Sutoyo, nilai-nilai keislaman dalam Konseling Islam meliputi: 1) nilai iman, yaitu nilai-nilai bimbingan dalam menjalankan rukun iman yang berupa penerapan prinsip keimanan dalam kehidupan nyata; 2) nilai Islam, yaitu nilai-nilai bimbingan dalam menjalankan rukun Islam yang berupa penerapan tuntunan ibadah dalam kehidupan nyata; dan 3) nilai ihsan, yaitu nilai-nilai bimbingan dalam menjalankan rukun ihsan yang berupa penerapan akhlakul karimah dalam kehidupan nyata ${ }^{21}$.

Pada konteks penelitian ini nilai bimbingan yang paling relevan adalah nilai ihsan, sebab binwin merupakan pelayanan sosial (mu'ámalah) dalam kehidupan nyata yang secara Islami wajib menerapkan akhlakul karimah (akhlak yang mulia). Menurut Yunahar Ilyas:

..... bahwa dalam akhlak tercakup pengertian terciptanya keterpaduan antara kehendak Khaliq (Tuhan) dengan perilaku makhlúq (manusia). Atau dengan kata lain, tata perilaku seseorang terhadap orang lain dan lingkungannya baru mengandung nilai akhlak yang hakiki manakala tindakan atau perilaku tersebut didasarkan kepada kehendak Khaliq ..... akhlak bukan saja merupakan tata aturan atau norma perilaku yang mengatur hubungan antar sesama manusia, tetapi juga norma yang mengatur hubungan antara manusia dengan Tuhan dan bahkan dengan alam semesta sekalipun ${ }^{22}$.

${ }^{20}$ Sutoyo, Anwar. 2014. Bimbingan \& Konseling Islami (Teori dan Praktik). Yogyakarta: Pustaka Pelajar. 22

${ }^{21}$ Sutoyo, Anwar. 2014. Bimbingan .... 149-192

22 Ilyas, Yunahar. 2014. Kuliah Akhlaq. Yogyakarta: Lembaga Pengkajian dan Pengamalan Islam. 1 


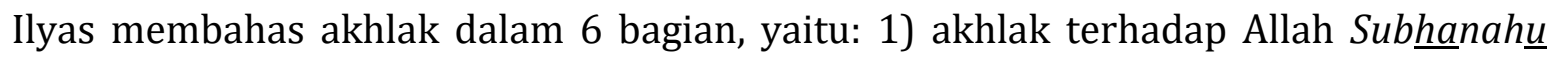
Wa Ta'al $\underline{a}, 2)$ akhlak terhadap Rasulullah Shallahu 'Alayhi Wasallam, 3) akhlak pribadi, 4) akhlak dalam keluarga 5) akhlak bermasyarakat, dan 6) akhlak bernegara ${ }^{23}$.

Sampai di sini dapat didefinisikan bahwa "konseling Islam" ialah sebuah hubungan antara seorang konselor yang butuh membantu dan seorang klien yang butuh dibantu dalam suatu proses interaksi pemberian bantuan atau bimbingan psikologis berdasarkan tuntunan Islam sehingga klien mampu memahami serta menyelesaikan masalahnya demi keselamatan dan kebahagiaan hidupnya baik di dunia maupun di akhirat.

Definisi tersebut dioperasionalisasikan dengan mengkombinasikan teori Konseling umum dan nilai keislaman yang memberikan karakter khusus. Proses konseling dianalisis kesesuaiannya dengan Konseling Islam menggunakan 2 tinjauan, yaitu: 1) analisis dalam tinjauan teori Konseling, dan 2) analisis dalam tinjauan nilai keislaman. Kesimpulan tentang ada/ tidaknya kesesuaian tersebut diarahkan pada kesesuaian terhadap teori Konseling dan nilai keislaman, yakni nilai ihsan yang berupa akhlak tertentu yang mewarnai aktivitas konseling.

Pada prinsipnya proses konseling Islam sama dengan proses konseling pada umumnya. Yang membedakan adalah: 1) konseling pada umumnya menggunakan pendekatan psikologis murni, sedangkan konseling Islam menggunakan pendekatan psikologis dan agama Islam; dan 2) konseling pada umumnya bertujuan untuk memahami dan menyelesaikan masalah, sedangkan konseling Islam selain memahami serta menyelesaikan masalah juga memenuhi kebutuhan fitrah manusia yakni mempedomani tuntunan Islam agar memperoleh keselamatan dan kebahagiaan yang sejati baik di dunia maupun di akhirat.

Sebagaimana langkah konseling Williamson ${ }^{24}$, proses Konseling Islam meliputi: analisis, sintesis, diagnosis, prognosis, terapi konseling, dan tindak lanjut. Hanya saja pendekatan psikologis yang dilakukan bersifat Islami. Tujuannya untuk memahami serta menyelesaikan masalah klien, memenuhi kebutuhan fitrahnya berdasarkan tuntunan Islam, demi memperoleh keselamatan dan kebahagiaan yang sejati baik di dunia maupun di akhirat.

Materi konseling ditentukan oleh ragam konseling. Anwar membagi ragam konseling dalam 3 tinjauan, yaitu: 1) dari aspek arenanya, terbagi atas konseling: individual, kelompok, pasangan suami istri, keluarga, dan kehidupan pribadi; 2) dari aspek settingnya, terbagi atas konseling: relawan, layanan sosial, layanan media,

${ }^{23}$ Ilyas, Yunahar. 2014. Kuliah ..... 6

${ }^{24}$ Effendi, Kusno. 2016. Proses .... 69-71

Al-Manar : Jurnal Komunikasi dan Pendidikan Islam - Volume 10, Nomor 1, Juni 2021 
pendidikan, tempat kerja, individual, dan waktu singkat; dan 3) dari aspek temanya, terbagi atas konseling: gender, ras, karir, keagamaan, traumatis, dan lintas budaya 25 .

Materi konseling dapat diolah dari kombinasi atas unsur-unsur pada ketiga aspek tersebut. Untuk materi konseling Islam, kombinasinya harus diwarnai dengan nilai-nilai keislaman. Maka materinya dapat dirinci menjadi 6 tema besar, yaitu materi bertema: 1) gender dalam perspektif Islam, 2) ras dalam perspektif Islam, 3) karir dalam perspektif Islam, 4) keislaman pada umumnya, 5) traumatis dalam perspektif Islam, dan 6) lintas budaya dalam perspektif Islam. Tema besar diopersionalkan sesuai dengan arena dan setting konselingnya, dikembangkan menjadi materi-materi variatif yang up to date.

Sebagaimana konseling umum, konseling Islam merupakan proses memberikan bantuan psikologis dalam hal mengungkap dan menyelesaikan masalah, kepada individu ataupun kelompok, menggunakan pendekatan tertentu. Metodenya meliputi: 1) pengamatan terlibat (onservasis partisipatif) dan tak terlibat (observasi nonpartisipatif); 2) wawancara (interview) konseling, dan 3) diskusi konseling.

Secara teknik, penerapan metode tersebut dalam bentuk: 1) konseling individual, dan 2) konseling kelompok. Komunikasinya bisa bersifat: 1) konseling langsung (directive counseling), 2) konseling tidak langsung (non directive counseling), dan 3) konseling yang selektif (selective counseling). ${ }^{26}$. Dalam Konseling Islam, penerapan metode-metode tersebut didasarkan atas nilai-nilai: iman, Islam, ataupun ihsan sehingga konseling berciri khas Islam.

Dalam konteks penelitian ini, PAIF dikatakan berperan secara ideal jika ia menjalankan perannya itu secara Islami dan legal. Dikatakan Islami karena peran yang dijalankannya sesuai dengan nilai-nilai Islam, dan dikatakan legal karena sesuai dengan payung hukum pada ranah tupoksinya.

Nilai-nilai Islam didahulukan daripada legalitas karena pada dasarnya segala aktivitas pelayanan PAIF harus menggunakan bahasa (pendekatan) agama Islam. Dengan demikian aktivitas pelayanan tersebut sudah memiliki pertanggungjawaban dasar, yakni tanggung jawab secara syari'at. Adapun nilai-nilai legalitas diperlukan agar aktivitas pelayanan PAIF dapat dipertanggungjawabkan secara hukum sesuai dengan tupoksinya. Selanjutnya secara teknis peranan-peranan itu dialankan dengan menjalin sinergitas bersama pihak terkait, sehingga peran tersebut dapat dibuktikan dari posisi subjektif PAIF dalam setting sosial, yakni di KUA tempatnya bertugas.

25 Sutoyo, Anwar. 2014. Bimbingan .... 20

26 UNY, Tim Dosen PPB FIP. 2013. Bimbingan Konseling Sekolah Menengan. Yogyakarta: Fakultas Pendidikan Uiversitas Negeri Yogyakarta. 36 
Sumber nilai-nilai Islam yang mendasari pelaksanaan tugas PAIF adalah AlQur'an dan Al-Hadits. Dalam konteks tupoksi PAIF secara umum, nilai-nilai yang diaplikasikan adalah nilai-nilai yang tergolong dalam nilai ihsan, yakni akhlak bermasyarakat yang berupa akhlak berdakwah, yakni menyeru ke jalan Allah secara bijaksana dan menggunakan nasihat serta diskusi yang baik

Dalam konteks binwin (dan konseling pada umumnya), nilai-nilai yang diaplikasikan adalah nilai-nilai yang tergolong dalam nilai ihsan, terutama pada 3 macam akhlak bermasyarakat, yaitu: 1) Akhlak saling tolong-menolong, 2) Akhlak saling memberi nasihat, dan 3) Akhlak menerima (memuliakan) tamu. Tiga nilai tersebut merupakan nilai-nilai Islam yang mendasar dalam binwin, sebab pada prinsipnya kegiatan binwin (yang bertumpu pada penasihatan pernikahan) itu pada dasarnya adalah kegiatan saling tolong-menolong, saling memberi nasihat, dan memuliakan tamu yang datang.

Selanjutnya tentang legalitas; payung hukum yang menaungi keberadaan PAIF adalah: 1) Peraturan Pemerintah Nomor 16 Tahun 1994 tentang Jabatan Fungsional Pegawai Negeri Sipil, 2) Keputusan Presiden Republik Indonesia (selanjutnya disingkat Keppres) Nomor 87 Tahun 1999 tentang Rumpun Jabatan Fungsional, 3) Keputusan Menkowasbangpan No. 54/KEP/MK.WASPAN/9/1999 tentang Jabatan Fungsional Penyuluh Agama dan Angka Kreditnya, dan 4) Keputusan Bersama Menteri Agama RI dan Kepala BKN No. 574 Tahun 1999 dan No. 178 Tahun 1999 tentang Petunjuk Pelaksanaan Jabatan Fungsional Penyuluh Agama dan Angka Kreditnya. Payung-payung hukum tersebut mengokohkan legalitas PAIF, baik dalam menjalankan tugas pokok maupun fungsinya. Adapun tugas pokok PAIF sebagaimana yang disebutkan dalam Kep. Menkowasbangpan No. 54/ KEP/MK.WASPAN/9/1999 pada bab I pasal 4 adalah melakukan dan mengembangkan kegiatan bimbingan atau penyuluhan agagama dan pembangunan melalui bahasa Agama27.

Berpijak pada tugas pokok tersebut, yang kemudian dikuatkan dengan diterbitkannya Keputusan Menteri Agama RI No. 516 Tahun 2003 tentang Petunjuk Teknis Pelaksanaan Jabatan Fungsional Penyuluh Agama Islam dan Angka Kreditnya, maka dalam pelaksanaan tugas PAIF melekat fungsi-fungsi PAIF. Adapun fungsi PAIF mengacu pada tugas pokoknya, dalam hal ini fungsi PAIF telah diatur menjadi 3 fungsi pokok, yakni: fungsi informatif dan edukatif; fungsi konsultatif; dan fungsi advokatif 28 . Ketiga fungsi ini menjadi dasar pelaksanaan tugas PAIF dalam melayani masyarakat, termasuk pada pelayanan binwin. Data observasi dan interview menunjukkan bahwa

27 jdih.bkn.go.id. Kep. Menkowasbangpan Nomor 54/KEP/MK.WASPAN/9/1999 tentang Jabatan Fungsional Penyuluh Agama dan Angka Kreditnya. pdf. 4

${ }^{28}$ Masyarakat, Bidang Pendidikan Agama Islam Pada. 2010. Buku .... 281-282

Al-Manar : Jurnal Komunikasi dan Pendidikan Islam - Volume 10, Nomor 1, Juni 2021 
PAIF telah berperan secara ideal, sebab peran-perannya dijalankan secara Islami dan legal.

Data penelitian ini tersentral pada subjek penelitian, yakni PAIF se-Kabupaten Sleman. Berdasarkan strata pendidikan 75 \% PAIF berpendidikan S1: 58,33 \% lakilaki dan 16,66 \% perempuan; dan $25 \%$ S2: terdiri atas 16,66 \% laki-laki dan 8,33\% perempuan. Dari tinjauan kompetensi 80,56 \% tidak berlatar belakang pendidikan pada bidang Konseling. Yang berlatar belakang bidang Konseling 19,44 \%; terdiri atas 11,11 \% laki-laki dan 8,33 \% perempuan. Dalam penelitian ini ditemukan bahwa potensi PAIF S2 bidang Konseling belum diberdayakan pada kajian atau diskusi bertema konseling.

Pada konteks binwin, PAIF merupakan salah satu unsur sumber daya manusia (SDM) di KUA. Sedangkan SDM lainnya adalah seluruh pegawai di KUA, terutama Kepala KUA, Penghulu, dan Staf Binwin KS. Selain itu masih ada mitra KUA yakni BP4. SDM pokok BP4 adalah para pengurus harian, anggota, dan Konselor Perkawinan. Dalam konteks penelitian ini eksistensi BP4 tidak bisa diharapkan. Sejak tahun 2000 BP4 mengalami penurunan, bahkan di sejumlah kecamatan terjadi kemacetan. Ditemukan bahwa eksistensi BP4 kecamatan tidak dapat diandalkan.

Kebutuhan masyarakat yang paling nyata pada BP4 adalah pada konteks legalitas penasihatan perkawinan. Upaya Kepala KUA dalam mencukupkan fungsi BP4 adalah menunjuk personil di KUA menjadi Konsultan Perkawinan. Personil tersebut bisa dari unsur staf ataupun PAIF. Data lapangan menunjukkan bahwa PAIF yang ditunjuk menjadi: 1) konsultan tetap sebanyak 35,3 \%: terdiri atas 23,5 \% laki-laki dan 11,5 \% perempuan; dan 2) konsultan insidentil sebanyak 64,7 \%. Ditemukan bahwa sarana binwin di KUA secara umum kondusif.

Dalam melaksanakan tugas pokoknya PAIF harus melakukan 2 hal. Pertama, menyusun sejumlah program kegiatan dengan pendekatan agama Islam sehingga kegiatannya bersifat Islami (sesuai dengan nilai-nilai Islam). Kedua, bersinergi dengan berbagai unsur di dalam masyarakat. Pada konteks binwin ia (dapat) menggunakan pendekatan konseling Islam dan bersinergi dengan Kepala dan staf di KUA, khususnya Penghulu dan Staf Binwin KS.

Hubungan sinergi antara PAIF dengan Penghulu dan Staf Binwin KS sudah sejalan dengan rincian tugas pokok PAIF yang menjadi kegiatan standarnya, yaitu: 1) Menyusun rencana kerja operasional; 2) Menyusun konsep tertulis materi bimbingan atau penyuluhan dalam bentuk naskah; 3) Melaksanakan bimbingan atau penyuluhan melalui tatap muka kepada masyarakat pedesaan; 4) Melaksanakan bimbingan atau penyuluhan melalui tatap muka kepada kelompok terpencil; 5) Melaksanakan bimbingan atau penyuluhan melalui pentas pertunjukan sebagai pemain; 6) 
Menyusun laporan mingguan pelaksanaan bimbingan atau penyuluhan; 7) Melaksanakan konsultasi secara perorangan; 8) Melaksanakan konsultasi secara kelompok; dan 9) Menyusun laporan hasil konsultasi perorangan/kelompok ${ }^{29}$. Dalam konteks binwin kegiatan PAIF terkonsentrasi pada butir ke-7, ke-8, dan ke-9, yakni melaksanakan serta menyusun laporan konsultasi secara perorangan dan kelompok dalam bidang keagamaan pada umumnya, dalam bidang perkawinan pada khususnya. Dengan demikian maka seharusnyalah PAIF berperan dalam binwin di KUA tempatnya bertugas.

Penting ditegaskan bahwa binwin merupakan salah satu aspek dari pelayanan perkawinan di KUA. Artinya masih ada aspek lain pada pelayanan tersebut. Maka untuk meneliti peran PAIF di dalamnya harus terlebih mencermati kedudukan binwin tersebut dalam keseluruhan pelayanan perkawinan. Dengan demikian peran tadi dapat teramati secara lebih menyeluruh. Disebut menyeluruh karena peran itu juga dikaitkan dengan perannya pada aspek lain dalam pelayanan pernikahan selain aspek binwin.

Aspek-aspek dalam pelayanan perkawinan di KUA dapat dikelompokkan menjadi 3 aspek, yaitu: 1) Pencatatan nikah ${ }^{30}$ yang meliputi; a) Pemberitahuan kehendak nikah, b) Pemeriksaan nikah, c) Pengumuman kehendak nikah, d) Akad nikah dan penandatanganan akta nikah, dan e) Pembuatan kutipan akta nikah; 2) Talak, cerai, dan rujuk ${ }^{31}$; dan 3) Penasihatan perkawinan ${ }^{32}$. Dalam hal iniPAIF dapat bersinergi dengan Penghulu dan Staf Binwin KS pada aspek penasihatan perkawinan, sebab aspek ini sesuai dengan tupoksi PAIF.

Yang dimaksud dengan penasihatan perkawinan adalah sebagaimana yang didefinisikan di dalam buku Pedoman Pembantu Pegawai Pencatat Nikah:

Penasihatan perkawinan adalah suatu pelayanan sosial mengenai masalah keluarga, khususnya hubungan suami istri, tujuan yang hendak dicapai ialah terciptanya situasi yang menyenangkan dalam suatu hubungan suami istri, sehingga dengan situasi yang menyenangkan tersebut keluarga dapat mencapai kebahagiaan ${ }^{33}$.

Dalam praktek sehari-hari di KUA, istilah "penasihatan perkawinan" lebih familiar disebut dengan "bimbingan perkawinan". Yang membedakan keduanya adalah pada konteks penerapannya. "Penasihatan perkawinan" diterapkan pada

${ }^{29}$ Masyarakat, Bidang Pendidikan Agama Islam Pada. 2010. Buku .... 28-29

30 Pusat, Badan Kesejahteraan Masjid (BKM). 1991. Pedoman Pembantu Pegawai Pencatat Nikah. Jakarta: Badan Kesejahteraan Masjid (BKM) Pusat. 4-32

31 Pusat, Badan Kesejahteraan Masjid (BKM). 1991. Pedoman ..... 33-47

32 Pusat, Badan Kesejahteraan Masjid (BKM). 1991. Pedoman ..... 65-78

33 Pusat, Badan Kesejahteraan Masjid (BKM). 1991. Pedoman ...... 65 
konteks administratif. Sedangkan "bimbingan perkawinan" digunakan pada konteks pelaksanan layannan.

istilah "penasihatan perkawinan" dan "bimbingan perkwinan" digunakan pada konteks yang sesuai. Artinya, jika secara teknis deskripsinya lebih mudah menggunakan istilah tertentu maka istilah itulah yang akan dipakai. Yang dimaksud lebih mudah adalah lebih mudah dalam mendapatkan referensinya, baik data maupun teori. Yang pasti, "bimbingan perkawinan" sama artinya dengan "penasihatan perkawinan"; maka hakikat kegiatan bimbingan perkawinan (binwin) adalah kegiatan penasihatan perkawinan.

Pada prakteknya penasihatan perkawinan tidak hanya ditujukan kepada pasangan yang telah berumah tangga saja namun juga kepada catin guna memantapkan niat mereka dalam melangsungkan perkawinan, bahkan pada realitas keseharian di KUA justru peristiwa penasihatan catin lebih banyak daripada penasihatan kepada pasangan suami istri. Para catin sudah mulai mendapatkan penasihatan sejak mendaftar nikah sampai ketika melangsungkan ijab qabul. Adapun durasi dan teknis penasihatannya menyesuaikan sasaran dan tujuan yang akan dicapai.

Berdasarkan sasarannya, peneliti membedakan penasihatan perkawinan menjadi 3 macam, yaitu: 1) Penasihatan pranikah, yang meliputi; a) Penasihatan catin individual, b) Penasihatan catin berpasangan/ sepasang, dan c) Penasihatan catin klasikal; 2) Penasihatan akad nikah (khutbah nikah); dan 3) Penasihatan pascanikah, yang meliputi; a) Penasihatan pascanikah individual, dan b) Penasihatan pascanikah berpasangan.

Dari uraian tersebut dapat diringkas adanya 8 potensi peran ideal yang sesuai dengan tupoksi PAIF. Artinya, seharus nya PAIF dapat berperan dalam kedelapan peran potensial tersebut. Dalam hal ini peneliti akan menyebut peran-peran itu dengan kode-kode "peran" menggunakan akronim huruf "P", yakni: P1, P2, P3, P4, P5, P6, P7, dan P8. Tujuannya adalah untuk menyederhanakan pembahasan. Adapun penjelasannya adalah sebagai berikut: 1) P1=Menjadi narasumber penasihatan catin individual, 2) P2= Menjadi narasumber penasihatan catin berpasangan/ sepasang, 3) P3=Menjadi narasumber penasihatan catin klasikal (suscatin), 4) P4=Menjadi MC/ moderator/ panitia suscatin, 5) $\mathrm{P} 5=$ Menjadi khatib pada khutbah nikah, 6) P6=Menjadi narasumber penasihatan pascanikah individual, 7) P7=Menjadi narasumber penasihatan pascanikah berpasangan, dan 8) P8=Menjadi Konsultan Perkawinan BP4. Selanjutnya peneliti menyebut kedelapan peran tersebut sebagai delapan peran ideal PAIF dalam binwin. Adapun kesesuaiannya dengan nilai-nilai 
Islam akan dianalisis pada peran aktual PAIF, yakni pada realisasi peran tersebut dalam binwin.

Peran aktual PAIF merupakan potensi peran ideal yang dapat diaktualisasikan PAIF dalam melaksanakan tugasnya. Aktualisasi peran tersebut dikembalikan kepada subjektifitas PAIF dalam menentukan kuantitas dan perioritas perannya. Secara sosiologis, subjektifitas tersebut berkonsekwensi terhadap posisi sosialnya di KUA.

Kuantitas dan prioritas peran menentukan signifikasi dari peran aktual seorang PAIF. Artinya, semakin banyak jumlah peran yang diaktualisasikan maka semakin signifikan peran aktualnya. Sedangkan jumlah peran itu ditentukan oleh pilihan subjektif PAIF, peran mana saja yang akan diprioritaskannya; semakin banyak yang diprioritaskannya akan semakin banyak jumlah perannya

Dalam konteks tupoksi PAIF, dari kedelapan potensi peran idealnya ada peranperan yang dapat dikategorikan sebagai peran yang relevan dengan tupoksi PAIF dan ada pula yang paling relevan. Dikatakan relevan karena potensi-potensi peran itu dapat daktualisasikan oleh PAIF meskipun relevansinya dengan tupoksi tidak bersifat signifikan. Sedangkan disebut paling relevan karena relevansi peran-peran tersebut dengan tupoksi bersifat signifikan. Peran-peran yang paling relevan itu adalah: P1, P2, P3, P6, P7, dan P8. Selanjutnya peneliti menyebut keenam peran itu sebagai peran signifikan. Sedangkan sisanya tidak dikategorikan peran tidak signifikan karena: P4 tidak terkait secara langsung dengan tupoksi PAIF, dan P5 terkait langsung dengan tupoksi PAIF, namun peran tersebut bisa diatasi sendiri oleh wali nikah atau Penghulu, kemungkinannya terlalu kecil/ tidak ada bagi PAIF, terlebih PAIF perempuan.

Dari pengamatan terlibat (observasi partisipatif) dalam kegiatan-kegiatan rutin Pokjaluh Kabupaten Sleman terdata bahwa dari total 34 orang PAIF pada KUA seKabupaten Sleman menunjukkan signifikasi peran aktual (dalam binwin) yang berbeda-beda. Pada konteks ini peneliti mengkategorikan menjadi 4 signifikasi, yaitu: signifikan, cukup signifikan, kurang signifikan, dan tidak signifikan.

Dalam hal menentukan kategori tersebut peneliti menggunakan standar keseluruhan dari jumlah peran signifikan yang diambil, yaitu: 1) Dikategorikan signifikan (selanjutnya akan disingkat S) jika jumlah peran signifikannya 6 item, 2) Dikategorikan cukup signifikan (selanjutnya akan disingkat CS) jika jumlah peran signifikannya 4 atau 5 item, 3) Dikategorikan kurang signifikan (selanjutnya akan disingkat KS) jika jumlah peran signifikannya 2 atau 3 item, dan 4) Dikategorikan tidak signifikan (selanjutnya akan disingkat TS) jika jumlah peran signifikannya 0 atau 1 item. 
Data lapangan menunjukkan adanya peran ideal PAIF sebagai mitra terdekat Penghulu dan Staf Binwin KS, serta sebagai Konsultan Perkawinan. Ditemukan bahwa tidak semua PAIF berperan secara signifikan dalam binwin. Adapun signifikasi perannya adalah: 23,53 \% terkategori S, $41,17 \%$ CS, 17,65 \% KS, dan 17,65 \% TS. Jika signifikasi peran tersebut dikaitkan dengan latar belakang pendidikan di bidang Konseling, ternyata datanya menunjukkan bahwa dari semua PAIF tersebut: 1) yang telah berperan secara signifikan sebanyak $50,50 \%$; terbagi atas $16,64 \%$ pada posisi raking 1 dan 33,33 \% pada posisi ranking $2 ; 2$ ) yang perannya sudah cukup signifikan sebanyak 33,33 \%; terbagi atas 16,64\% pada posisi ranking 6 dan 16,64 \% pada posisi ranking 9 ; 3) yang perannya masih kurang signifikan sebanyak $16,64 \%$ dan berposisi pada ranking 13; dan 4) yang perannya tidak signifikan $0 \%$. Tidak adanya PAIF berpendidikan dibidang Konseling yang perannya tidak signifikan menunjukkan bahwa latar belakang pendidikan tersebut berpotensi meningkatkan kualitas peran PAIF dalam binwin.

Dari uraian tersebut peneliti mendapati temuan-temuan sebagai berikut: Pertama, adanya kesenjangan antara peran ideal (yang seharusnya dimainkan oleh PAIF) dengan peran aktual (yang dilakukannya dalam kegiatan binwin di KUA). Secara umum kesenjangan tersebut dilatarbelakangi oleh tidak teraktualisasinya peranperan tertentu. Dalam hal ini, dari potensi peran dengan kode: P1, P2, P3, P4, P5, P6, P7, dan P8 masih ada yang tidak teraktualisasi, khususnya peran dengan kode P4 dan P5. Hal ini sangat dimungkinkan karena relevansi P4 dan P5 tidak signifikan terhadap tupoksi PAIF sehingga pada umumnya PAIF tidak memprioritaskannya.

Kedua, adanya signifikasi peran aktual yang berbeda-beda antara PAIF yang satu dengan yang lain. Keberbedaan ini dilatarbelakangi oleh beberapa hal, yaitu; a) Tidak semua PAIF mengambil peran sebagai Konsultan Perkawinan BP4 dalam kategotri konsultan tetap, ada diantara mereka yang terkategori konsultan tidak tetap. Namun secara legal formal, posisi menjadi konsultan bergantung pada kebijakan (hasil penunjukan) Kepala KUA masing-masing. Hanya saja secara logika kewajaran dapat dipahami bahwa tidak mungkin Kepala KUA menunjuk PAIF yang tidak berkualitas. Dengan demikian posisi ini bisa dipandang sebagai bagian dari prestasi individual seorang PAIF. Prestasi tersebut adalah dalam konteks kepekaan dan kemampuan PAIF dalam merespon posisi startegisnya di KUA; b) Tidak semua PAIF mengambil peran pada penasihatan pranikah dan pascanikah secara penuh, bahkan ada yang hanya berperan pada penasihatan pranikah saja atau penasihatan pascanikah saja; c) Tidak semua PAIF memprioritaskan peran-peran yang tidak signifikan, sebagian besar memprioritaskan peran-peran yang signifikan saja; dan d) Tidak semua PAIF berlatar belakang pendidikan di bidang konseling. 
Ketiga, signifikasi peran PAIF (ideal dan aktual) sangat ditentukan oleh kepekaan dan kemampuan masing-masing PAIF dalam merespon posisi strategisnya di KUA. Selain itu, latar belakang pendidikan bidang konseling berpotensi meningkatkan kualitas peran PAIF tersebut. Sedangkan jenis kelamin tidak berpotensi meningkatkan kualitas tersebut. Selanjutnya peran ideal dan aktual tersebut akan ditinjau relevansinya dengan standar Konseling Islam.

Relevansi peran-peran tersebut dengan standar Konseling Islam adalah: 1) relevansi peran ideal yang terletak pada aspek: proses, bentuk layanan, bidang pelayanan, arena, setting, tema, dan nilai keislaman, dan 2) relevansi peran aktual yang terletak pada aspek: pendekatan, strategi, dan metode yang semuanya relevan dengan nilai keislaman. Ditemukan adanya relevansi antara konseling, konseling Islam, dan binwin sebagai hubungan himpunan bagian (union).

Ditemukan pula bahwa PAIF telah melakukan strategi optimalisasi peran agar relevan dengan standar Konseling Islam. Dalam hal ini PAIF telah menerapkan strategi referensional yang bersifat alamiah, yakni menjalankan tugas (pelayanan binwin) sesuai dengan referensi buku-buku pedoman.

Peneliti memandang perlu bagi PAIF mengembangkan strategi referensional itu. Selain itu; Pokjaluh (Kelompok Kerja Penyuluh) Kabup aten Sleman perlu memprioritaskan kajian atau diskusi penguatan strategi referensional, memberdayakan 19,44 \% PAIF yang berpendidikan S2 bidang Konseling, serta menyusun kurikulum diskusi dan kajian. Lebih jauh lagi, Kemenag

SKEMA HASIL PENELITIAN DAN PEMBAHASAN

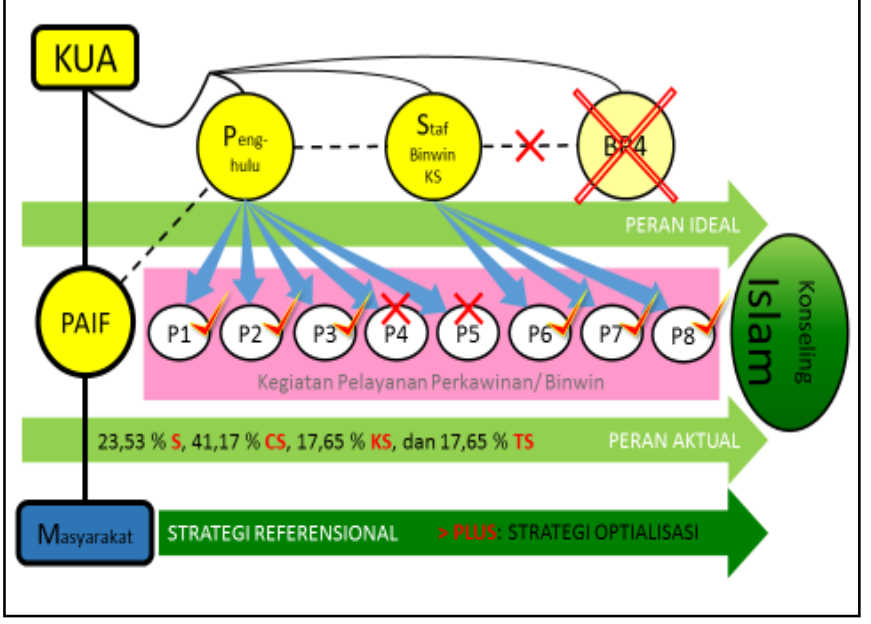

Gambar 2. Penjelasan Skematis Hasil Penelitian Dan Pembahasan Kabupaten Sleman perlu mengusahakan pendidikan dan latihan bimbingan konseling Islam serta meningkatkan peran dalam memberi izin/ tugas belajar kepada PAIF.

\section{KESIMPULAN}

Peneliti berkesimpulan bahwa: Pertama, peran PAIF dalam binwin di Kabupaten Sleman meliputi: a) Peran ideal sudah bersifat Islami dan legal. Dikatakan Islami karena peran yang dijalankan sesuai dengan nilai-nilai Islam, dan dikatakan 
legal karena sesuai dengan payung hukum pada ranah tupoksinya. Adapun kegiatannya bertumpu pada kegiatan penasihatan pranikah dan penasihatan pascanikah, yang terkelompok dalam 8 peran. Kedelapan peran itu terbagi atas 6 peran signifikan (yaitu menjadi narasumber penasihatan: catin individual, catin berpasangan/ sepasang, catin klasikal [suscatin], pascanikah individual, dan pascanikah berpasangan; serta menjadi menjadi Konsultan Perkawinan) dan 2 peran tak signifikan (yaitu menjadi moderator/ MC pada suscatin dan sebagai khatib pada akad nikah). Dalam hal ini PAIF berperan sebagai: mitra terdekat Penghulu pada pelayanan pendaftaran nikah dan mitra terdekat Staf Binwin KS pada pelayanan binwin, yaitu menjadi Konsultan Perkawinan yang mencukupkan legalitas BP4 Kecamatan pada pelayanan administrasi dan persuratan. b) Peran aktual sudah mencerminkan aktualisasi peran ideal PAIF dalam melaksanakan tugas binwin. Dalam hal ini PAIF cenderung bertumpu pada 6 peran signifikan saja karena peran tersebut sangat relevan dengan tupoksinya, sedangkan peran lainnya tidak relevan. Adapun signifikasi peran yang diaktualisasikan PAIF tersebut adalah: (1) Sebanyak 23,53\% (yakni 11,765 \% laki-laki dan 11,765 \% perempuan) berperan secara signifikan (S) yang artinya telah menjalankan 6 item peran signifikan, (2) Sebanyak 41,17\% (yakni $35,29 \%$ laki-laki dan 5,88 \% perempuan) berperan cukup signifikan (CS) yang artinya baru menjalankan 4 atau 5 item peran signifikan, (3) Sebanyak 17,65 \% (yakni 14,71 $\%$ laki-laki dan 2,94\% perempuan) berperan kurang signifikan (KS) yang artinya baru menjalankan 2 atau 3 item peran signifikan, dan (4) Sebanyak 17,65 \% (yakni $14,71 \%$ laki-laki dan 2,94 \% perempuan) berperan tidak signifikan (TS) yang artinya baru menjalankan 1 item peran signifikan atau bahkan tidak berperan.

Kedua, peran-peran PAIF tersebut telah relevan dengan standar Konseling Islam. Adapun relevansinya adalah sebagai berikut: a) Relevansi peran ideal PAIF terletak pada 7 tinjauan, yaitu: (1) Dari aspek proses merupakan proses layanan sosial, (2) Dari aspek bentuk layanan merupakan bantuan atau bimbingan psikologis, (3) Dari aspek bidang pelayanan tergolong pada bidang perkawinan, (4) Dari aspek arena telah memenuhi semua ragam konseling, (5) Dari aspek setting termasuk konseling layanan sosial, (6) Dari aspek tema termasuk konseling keagamaan, dan (7) Dari aspek nilai keislaman termasuk pada nilai ihsan, yakni akhlak bermasyarakat yang berupa akhlak: saling tolong-menolong, menerima tamu, saling memberi nasihat.

Ketiga, relevansi peran aktual PAIF terletak pada 3 tinjauan, yaitu: a) Dari aspek pendekatan menggunakan pedekatan Psikologi Islam alami (nutural Islamical Psychology approach), dan dari nilai keislaman termasuk pada nilai ihsan, yakni akhlak bermasyarakat yang berupa akhlak berbicara (berkomunikasi), b) Dari aspek 
strategi menggunakan strategi referensional, dan dari nilai keislaman berupa nilai ihsan, yakni akhlak bernegara yang berupa akhlak terhadap ulil amri (pemerintah), c) Dari aspek metode menggunakan metode pentahapan penasihatan yang relevan dengan teori langkah-langkah konseling dari Williamson. Sedangkan masing-masing tahapnya relevan dengan teori-teori konseling secara umum, dan relevansinya terhadap nilai-nilai keislaman berupa nilai ihsan, yaitu: (1) Akhlak pribadi yang berupa akhlak mengubah prilaku dengan menutup keburukan dengan kebaikan, (2) Akhlak bermasyarakat yang berupa akhlak dalam: berbicara, tolong-menolong, menerima tamu, melakukakn tabayun (klarifikasi) secara objektif sesuai dengan sumbernya, dan mendamaikan perselisihan, (3) Akhlak bernegara yang berupa akhlak dalam: mencatat (mengadministrasi) kegiatan muamalah yang lagal, bermusyawarah dalam urusan bersama, dan bertawakkal dalam menindaklanjuti kesepakatan musyawarah.

Keempat, strategi yang harus ditempuh guna mengoptimalisasikan peran PAIF dalam binwin agar relevan dengan standar Konseling Islam adalah: a) PAIF perlu menerapkan dan mengembangkan strategi referensional, b) Pokjaluh Kabupaten Sleman perlu menempuh langkah: (1) Memprioritaskan tema-tema kajian atau diskusi pada orientasi penguatan strategi referensional, (2) Memberdayakan 19,44 \% PAIF (yang berpendidikan S2 bidang konseling) menjadi narasumber kajian atau diskusi (yang bertema konseling) pada forum Pokjaluh guna menggali potensi akademik PAIF, (3) Menyusun kurikulum diskusi dan kajian dengan perbandingan tema yang diproyeksikan secara tepat guna memberikan prioritas khusus terhadap upaya penguatan kompetensi PAIF dalam binwin; c) Kemenag Kabupaten Sleman perlu menempuh langkah: (1) Mengusahakan pendidikan dan latihan bimbingan konseling Islam bagi seluruh PAIF, (2) Meningkatkan peran dalam memberikan kesempatan izin/ tugas belajar kepada PAIF untuk menempuh pendidikan pascasarjana MSI pada konsentrasi KKI dengan menjalin kerjasama dengan perguruan tinggi yang terakreditasi A.

\section{DAFTAR PUSTAKA}

Effendi, Kusno. 2016. Proses dan Keterampilan Konseling. Yogyakarta: Pustaka Pelajar. Ilyas, Yunahar. 2014. Kuliah Akhlaq. Yogyakarta: Lembaga Pengkajian dan Pengamalan Islam.

Ismail, Nawari. 2015. Metodologi Penelitian Untuk Studi Islam Panduan Praktis dan Diskusi Isu. Yogyakarta: Samudra Biru.

jdih.bkn.go.id. Kep. Menkowasbangpan Nomor 54/KEP/MK.WASPAN/9/1999 tentang Jabatan Fungsional Penyuluh Agama dan Angka Kreditnya. pdf. 
Kamus, Tim Penyusun. 2008. Kamus Bahasa Indonesia. Jakarta: Pusat Bahasa Departemen Pendidikan Nasional.

Khilmiyah, Akif. 2016. Metode Penelitian Kualitatif. Yogyakarta: Samudra Biru.

Masyarakat, Bidang Pendidikan Agama Islam Pada. 2010. Buku Pedoman Penyuluh Seri I. Yogyakarta: Kanwil Kementerian Agama DIY.

Pusat, Badan Kesejahteraan Masjid (BKM). 1991. Pedoman Pembantu Pegawai Pencatat Nikah. Jakarta: Badan Kesejahteraan Masjid (BKM) Pusat.

RI, Kementerian Agama. 2012. Al-Qur'an Dan Tafsirnya Jilid 7. Jakarta: Kementerian Agama RI Direktorat Jendral Bimbingan Masyarakat Islam Dan Pembinaan Syariah.

RI, Kementerian Agama. 2012. Al-Qur'an Dan Terjemahnya. Jakarta: Kementerian Agama RI Direktorat Jendral Bimbingan Masyarakat Islam Dan Pembinaan Syariah.

Soerjono, Soekanto. 1990. Sosiologi Suatu Pengantar. Jakarta: PT Raja Grafindo Persada.

Sutoyo, Anwar. 2014. Bimbingan \& Konseling Islami (Teori dan Praktik). Yogyakarta: Pustaka Pelajar.

Undang-Undang Republik Indonesia Nomor 1 Tahun 1974 Tentang Perkawinan dalam: Indonesia, Direktorat Jenderal Bimbingan Masyarakat Islam Kementerian Agama Republik. 2015. Himpunan Peraturan Perundang-Undangan Perkawinan. Jakarta: Direktorat Jenderal Bimbingan Masyarakat Islam Kementerian Agama Republik Indonesia.

UNY, Tim Dosen PPB FIP. 2013. Bimbingan Konseling Sekolah Menengan. Yogyakarta: Fakultas Pendidikan Uiversitas Negeri Yogyakarta. 